\title{
Staphylococcus aureus-A Known Opponent against Host Defense Mechanisms and Vaccine Development-Do We Still Have a Chance to Win?
}

\author{
Urszula Wójcik-Bojek (D), Barbara Różalska and Beata Sadowska *(D) \\ Department of Immunology and Infectious Biology, Faculty of Biology and Environmental Protection, \\ University of Lodz, Banacha 12/16, 90-237 Lodz, Poland; urszula.wojcik@biol.uni.lodz.pl (U.W.-B.); \\ barbara.rozalska@biol.uni.lodz.pl (B.R.) \\ * Correspondence: beata.sadowska@biol.uni.lodz.pl
}

Citation: Wójcik-Bojek, U.; Różalska,

B.; Sadowska, B. Staphylococcus

aureus-A Known Opponent against Host Defense Mechanisms and

Vaccine Development-Do We Still

Have a Chance to Win? Int. J. Mol.

Sci. 2022, 23, 948. https://doi.org/

10.3390/ijms23020948

Academic Editor: Andreas

Burkovski

Received: 17 December 2021

Accepted: 13 January 2022

Published: 16 January 2022

Publisher's Note: MDPI stays neutral with regard to jurisdictional claims in published maps and institutional affiliations.

Copyright: () 2022 by the authors Licensee MDPI, Basel, Switzerland. This article is an open access article distributed under the terms and conditions of the Creative Commons Attribution (CC BY) license (https:// creativecommons.org/licenses/by/ $4.0 /)$.

\begin{abstract}
The main purpose of this review is to present justification for the urgent need to implement specific prophylaxis of invasive Staphylococcus aureus infections. We emphasize the difficulties in achieving this goal due to numerous $S$. aureus virulence factors important for the process of infection and the remarkable ability of these bacteria to avoid host defense mechanisms. We precede these considerations with a brief overview of the global necessitiy to intensify the use of vaccines against other pathogens as well, particularly in light of an impasse in antibiotic therapy. Finally, we point out global trends in research into modern technologies used in the field of molecular microbiology to develop new vaccines. We focus on the vaccines designed to fight the infections caused by S. aureus, which are often resistant to the majority of available therapeutic options.
\end{abstract}

Keywords: Staphylococcus aureus; immune evasion; staphylococcal virulence factors; immune response; vaccines; molecular technologies; alternative therapies; antimicrobial resistance

\section{Introduction}

Over many decades it has been established that, thanks to vaccines, efficient hygiene procedures and antibiotics, successful treatment and limitation of infectious diseases spread can be easily achieved. Indeed, the discovery and use of antibiotics, considered one of the greatest advances in medicine, was, in the beginning, a very promising direction. Unfortunately, their widespread and not always proper use in medicine, veterinary medicine and agriculture contributes to a growing phenomenon of antimicrobial resistance (AMR), mostly as a consequence of selection pressure, including the development of multiple drug resistance (MDR). As a result, treatment options for the most severe infections have gradually decreased over the years. The progress of microbial drug resistance was and is faster than the introduction of new drugs. Considering the above, it is strongly justified return greater attention once again to the improvement of specific (immune) prophylaxis, i.e., protective vaccinations introduced into medicine much earlier than antibiotic therapy. It is worth emphasizing that the efficacy of a vaccination is independent of the drug resistance profile of pathogens. Therefore, vaccines are a valuable weapon against microorganisms possessing an AMR/MDR phenotype. Moreover, the benefits of vaccination are much broader and include: (i) lowering the use of antimicrobial compounds, (ii) limiting the selection of resistant serotypes and (iii) reducing the infection rate of resistant strains in closely related species [1].

Ten years ago, the World Health Assembly endorsed the Global Vaccine Action Plan (GVAP) for 2011-2020. According to it, the indicated decade was expected to reduce the number of global deaths due to infectious diseases by ten times ( 25 million people). However, the analysis by the Strategic Advisory Group of Experts on Immunization (SAGE) of the World Health Organization (WHO) showed this goal was not met. It also suggested 
that due to a large backlog in this area, uneven contributions from individual countries and small financial outlays, it would not be possible to reach it in the near future. In addition, the COVID-19 pandemic situation has contributed significantly to the slowing down of the ability to achieve the GVAP targets. According to the experts, in order to extend the beneficial impact of vaccines and vaccination on global health, new vaccines for other diseases, as well as improved supply and delivery mechanisms, need to be developed [2].

Based on the information provided by the WHO, the list of infectious diseases / etiological agents targeted for vaccination and globally available comprises 16 items with the prevalence of viruses. Novel cell targets pending the urgent modification of the composition of current antibacterial vaccines or the development of an entirely new framework and formulations are needed. The list of vaccines that may be much more effective after improvement includes those against the following bacterial species: Bordetella pertussis, Streptococcus pneumoniae, Neisseria meningitidis, Haemophilus influenzae [3-6]. In addition to the vaccines already on this WHO list, there are important targets (viruses and bacteria) for new vaccines that are currently of little social, scientific, financial and manufacturing interest. Furthermore, the inventory of new "neglected" species of bacteria or those for which no vaccine has been developed, despite attempts, is also long and includes: Group A, B Streptococcus (S. pyogenes, S. agalactiae), invasive non-typhoid Salmonella (iNTS), Shigella sp., Pseudomonas aeruginosa, Acinetobacter sp. and Staphylococcus aureus. Although many different vaccine formulations have been proposed to prevent infections caused by some of the AMR pathogens (e.g., S. aureus, Escherichia coli, Clostridioides difficile), no successful phase III clinical trial data have been published yet. The multiple virulence mechanisms that a vaccine should target are among the numerous other possible reasons for the failure to develop vaccines against these pathogens $[1,2,7,8]$.

In this review, the authors intend to provide the rationale for accelerating the research, pre-clinical and clinical trials needed to introduce a vaccine against $S$. aureus into immunotherapy. We highlight important reasons for this call to action, as well as the challenges. The background for these considerations is a description of the effective "abilities" of $S$. aureus to bypass/overcome/avoid the defense forces of the host, acting at particular stages of local or systemic infection. A presentation of the "history" of the proposed vaccines with the "pros and cons" arguments for selecting the individual S. aureus virulence factors as their components is also included. Finally, we discuss the trends in immune prophylaxis against $S$. aureus as well as several alternative strategies for combating this and other "difficult" bacteria.

\section{S. aureus Infections as a Challenge to Vaccinology: Why Is It Important?}

Staphylococcus aureus is a Gram-positive pathogenic bacterium that may be found on the skin and mucous membranes of humans and several animal species. S. aureus colonizes the nares or nasopharynx of about $30 \%$ of a population in an asymptomatic manner and becomes pathogenic after breaching epithelial barriers, making colonization an important risk factor [9-12]. These bacteria are the most common human pathogens, causing a wide variety of nosocomial and community-acquired infections. Typical staphylococcal infections range from minor skin and soft tissue infections, such as abscesses, furuncles and impetigo, to life threatening diseases, such as bacteremia, sepsis and toxic shock syndrome. In addition, $S$. aureus is a leading causative agent in surgical site infections, biomaterialassociated infections (e.g., catheters, artificial heart valves, bone and joint prostheses), cardiovascular infections, respiratory tract infections and food poisoning [13-16]. Epidemiological data show that $S$. aureus bacteremia leads to approximately 20,000 deaths a year in the USA, which accounts for more deaths than those from AIDS, tuberculosis and viral hepatitis combined together [17,18]. Furthermore, patients with risk factors (e.g., diabetics, immunocompromised, transplant recipients, oncological patients) are prone to developing severe staphylococcal infections and may require more frequent hospitalization [15,19-21]. In healthcare settings, $S$. aureus spreads rapidly, not only due to transmission from patients or medical staff, but also due to the ability of these microorganisms to survive on medical 
equipment and various hospital surfaces. The contamination of indwelling devices and implants represents a frequent route of infection because $S$. aureus easily adheres to abiotic surfaces, as well as to the matrix molecules that coat the devices after insertion. Staphylococci can also be transferred from the skin/mucous membranes of patient or healthcare personnel during surgery or other treatment and care procedures [21-23].

Treatment of staphylococcal infections is particularly problematic due to the constantly increasing acquisition of resistance genes and selection of antibiotic resistant $S$. aureus strains. Both community- and hospital-acquired methicillin-resistant S. aureus (CA-MRSA, HA-MRSA), representing multidrug-resistant strains (MDR), spread very quickly $[16,24,25]$. MRSA infections are associated with higher mortality and longer hospital stays than the infections caused by other pathogens, including methicillin-sensitive S. aureus (MSSA) [26-28]. Vancomycin was a last resort antibiotic for many years in such cases, but clinical isolates of vancomycin-resistant $S$. aureus (VRSA) have emerged and become a major public health concern $[16,29]$. Resistance to traditional beta-lactams and other available antibiotics limits the therapeutic options for treating these infections. The antibiotics currently approved for use in severe cases include glycopeptides, such as teicoplanin or dalbavancin, linezolid, tedizolid, daptomycin, tigecycline and cephalosporins of the fifth generation (ceftaroline, ceftobiprol) [16]. Finally, during the infection process, the staphylococci frequently form biofilms on both the inserted/implanted biomaterials and host tissues, which once established are difficult to eradicate and tend to recur.

A biofilm is a complex microbial community embedded in a self-made extracellular polymeric substance (EPS) that can be free-floating or attached to biotic or abiotic surfaces [30-32]. Bacteria in a biofilm exhibit different metabolism, gene transcription and protein production than during planktonic growth, which means completely new properties [33-35]. From the clinical point of view, one of the most important features is the higher tolerance of biofilms to environmental factors, which results in a weakened effect of antimicrobial drugs and impaired function of the host defense mechanisms [21,36,37]. The multifactorial tolerance/resistance of biofilms contributes to huge difficulties in combating biofilm-associated infections (BAI). Despite numerous studies regarding the new treatment methods of BAI, surgical excision of the infected tissue or removal of a colonized device is still the only viable solution in some cases [22].

\section{S. aureus Immune Evasion Strategies}

The success of $S$. aureus as a pathogen depends on its ability to produce multiple virulence factors simultaneously and to regulate their expression quickly in response to environmental changes. As shown in Table 1, these factors allow staphylococci adhesion to the cell membranes or extracellular matrix proteins/glycoproteins as well as invasion of the host tissues. Then, they make them capable of avoiding immune response, which consequently leads to the spread of infection and serious damage throughout the body [38]. Selected mechanisms of this pathogen that interfere with the innate and adaptive immune system are discussed below.

One of the first barriers of a host's innate immunity that S. aureus encounters during infection is the complement system-a proteolytic cascade of plasma proteins that can opsonize $S$. aureus cells, which promote their phagocytosis and killing by neutrophils (PMN-polymorphonuclear cells) and macrophages (M). Complement proteins may also lyse microbial cells directly by the activation and formation of a membrane attack complex (MAC) on the surface of the pathogen cell membrane $[39,40]$. The complement system can be activated through three activation routes (classical, lectin and alternative), and all of them result in the deposition of $\mathrm{C} 3 \mathrm{~b}$ on the staphylococcal surface. The C3a formed at the same time is an anaphylatoxin with a range of functions in inflammatory response, including macrophage and $\mathrm{T}$ cell activation as well as chemotaxis. 
Table 1. The most important virulence factors of $S$. aureus and their targets during infection $[38,41,42]$.

\begin{tabular}{|c|c|c|c|}
\hline $\begin{array}{l}\text { Type of Virulence } \\
\text { Factor }\end{array}$ & Name & Target & Effect \\
\hline \multirow{9}{*}{$\begin{array}{l}\text { Cell } \\
\text { wall-associated } \\
\text { factors }\end{array}$} & $\begin{array}{c}\text { Cell wall } \\
\text { components-peptidoglycan, } \\
\text { teichoic acid, lipoteichoic acid }\end{array}$ & $\begin{array}{l}\text { Immune cells, other } \\
\text { tissues }\end{array}$ & $\begin{array}{l}\text { Stimulate immune cell activation and } \\
\text { inflammatory response; participate in } \\
\text { adhesion and biofilm formation }\end{array}$ \\
\hline & $\begin{array}{l}\text { Staphylococcal protein A } \\
\text { (SpA) }\end{array}$ & IgG, IgM, complement & $\begin{array}{c}\text { Binds Fc region of IgG and IgM, thus } \\
\text { inhibiting opsonization and phagocytosis; } \\
\text { activates B cells }\end{array}$ \\
\hline & $\begin{array}{l}\text { Fibronectin-binding proteins } \\
\text { (FnBPA, FnBPB) }\end{array}$ & $\begin{array}{l}\text { Fibronectin, fibrinogen, } \\
\text { elastin, plasminogen, } \\
\text { keratin, complement }\end{array}$ & $\begin{array}{c}\text { Binding to extracellular matrix proteins } \\
\text { (ECM), enable adhesion to host tissues and } \\
\text { biomaterials; limit phagocytosis and } \\
\text { complement activation }\end{array}$ \\
\hline & $\begin{array}{l}\text { Collagen-binding protein } \\
\text { (Cna) }\end{array}$ & $\begin{array}{c}\text { Cartilage and } \\
\text { collagen-rich tissues, } \\
\text { complement }\end{array}$ & $\begin{array}{l}\text { Binding cartilage and collagen, enables } \\
\text { adhesion to host tissues; inhibits } \\
\text { complement activation }\end{array}$ \\
\hline & Clumping factors (ClfA, ClfB) & $\begin{array}{l}\text { Fibrinogen, blood } \\
\text { platelets, complement } \\
\text { (ClfA), cytokeratin } 10 \\
\text { (ClfB) }\end{array}$ & $\begin{array}{c}\text { Binding to fibrinogen, enables adhesion to } \\
\text { host tissues; inhibit complement preventing } \\
\text { opsonization and phagocytosis; } \\
\text { activate platelets }\end{array}$ \\
\hline & $\begin{array}{l}\text { Serine-aspartate repeat } \\
\text { protein E (SdrE) }\end{array}$ & Complement & $\begin{array}{l}\text { Inhibits complement preventing } \\
\text { opsonization and phagocytosis }\end{array}$ \\
\hline & $\begin{array}{l}\text { Iron-regulated } \\
\text { surface determinant proteins } \\
\text { (IsdA, IsdB) }\end{array}$ & Heme-iron & $\begin{array}{l}\text { Heme uptake and iron acquisition contribute } \\
\text { to increased pathogenesis, tissue invasion } \\
\text { and abscess formation }\end{array}$ \\
\hline & $\begin{array}{c}\text { Polysaccharide intercellular } \\
\text { adhesion/polymeric } \\
\text { N-acetyl-glucosamine } \\
\text { (PIA/PNAG) }\end{array}$ & $\begin{array}{l}\text { Staphylococcal cells, } \\
\text { mucous membranes, other } \\
\text { tissues, abiotic surfaces }\end{array}$ & $\begin{array}{l}\text { Participates in bacterial aggregation, } \\
\text { adhesion and biofilm formation (major } \\
\text { component of biofilm matrix); } \\
\text { reduces phagocytosis }\end{array}$ \\
\hline & Capsular polysaccharides & $\begin{array}{l}\text { Mucous membranes, other } \\
\text { tissues, abiotic surfaces }\end{array}$ & $\begin{array}{c}\text { Reduce phagocytosis; increase the efficiency } \\
\text { of colonization and durability on the surface } \\
\text { of mucous membranes or biomaterials }\end{array}$ \\
\hline \multirow{7}{*}{ Enzymes } & Catalase & Hydrogen peroxide & $\begin{array}{c}\text { Catalyzes breakdown of hydrogen peroxide } \\
\text { into water and oxygen, preventing } \\
\text { oxidative stress }\end{array}$ \\
\hline & Coagulase & Prothrombin & $\begin{array}{l}\text { Reacts with prothrombin, allowing } \\
\text { fibrinogen polymerization and clot } \\
\text { formation, thus reducing phagocytosis }\end{array}$ \\
\hline & Staphylokinase (SAK) & Plasminogen & $\begin{array}{l}\text { Converts plasminogen to active serine } \\
\text { protease plasmin, which promotes } \\
\text { degradation of ECM, complement and IgG }\end{array}$ \\
\hline & Lipases & $\begin{array}{l}\text { Lipids of cell membranes } \\
\text { and components of sebum }\end{array}$ & $\begin{array}{l}\text { Decompose lipids, which allows spreading } \\
\text { of staphylococci }\end{array}$ \\
\hline & Nucleases & Nucleic acids & $\begin{array}{l}\text { Degrade nucleic acids, thereby releasing } \\
\text { them from extracellular traps (ETs) }\end{array}$ \\
\hline & $\begin{array}{c}\text { Proteases, e.g., serine protease } \\
\text { V8 (SspA), staphopain A (Scp } \\
\text { A) and B (SspB), aureolysin } \\
\text { (Aur) }\end{array}$ & $\begin{array}{l}\text { ECM proteins, } \\
\text { complement, mucins, } \\
\text { pulmonary surfactant }\end{array}$ & $\begin{array}{l}\text { Degrade ECM proteins, mucins and } \\
\text { pulmonary surfactant, which allow } \\
\text { staphylococcal spread in the host tissues; } \\
\text { inhibit chemotaxis and phagocytosis by } \\
\text { proteolysis of immune cell receptors; } \\
\text { degrade complement preventing } \\
\text { opsonization and lysis of bacteria; degrade } \\
\text { antimicrobial peptides }\end{array}$ \\
\hline & Superoxide dismutases & Superoxide & $\begin{array}{l}\text { Convert superoxide to hydrogen peroxide } \\
\text { and oxygen, thereby preventing } \\
\text { oxidative stress }\end{array}$ \\
\hline
\end{tabular}


Table 1. Cont.

\begin{tabular}{|c|c|c|c|}
\hline $\begin{array}{l}\text { Type of Virulence } \\
\text { Factor }\end{array}$ & Name & Target & Effect \\
\hline \multirow{5}{*}{ Toxins } & $\begin{array}{l}\text { Hemolysins (alpha, beta, } \\
\text { gamma, delta) }\end{array}$ & $\begin{array}{l}\text { Erythrocytes, platelets, } \\
\text { leukocytes }\end{array}$ & $\begin{array}{l}\text { Cause lysis of red blood cells, platelets, } \\
\text { leukocytes—evading of host immune } \\
\text { response; bacterial spreading }\end{array}$ \\
\hline & Enterotoxins & $\begin{array}{c}\text { Enterocytes, lymphocytes } \\
\mathrm{T}\end{array}$ & $\begin{array}{l}\text { Cause diarrhea; after translocation into } \\
\text { blood, activate lymphocytes T leading to } \\
\text { cytokine storm }\end{array}$ \\
\hline & Exfoliative toxins & $\begin{array}{l}\text { Desmosomes between } \\
\text { keratinocytes }\end{array}$ & $\begin{array}{l}\text { Cleave the granular layer of the epidermis by } \\
\text { damaging desmosomes (staphylococcal } \\
\text { scalded skin syndrome) }\end{array}$ \\
\hline & $\begin{array}{c}\text { Panton-Valentine leukocidin } \\
\text { (PVL) }\end{array}$ & $\begin{array}{l}\text { Neutrophils, monocytes, } \\
\text { macrophages }\end{array}$ & $\begin{array}{l}\text { Causes lysis of neutrophils, monocytes, } \\
\text { macrophages—avoiding innate immune } \\
\text { response; development of necrotic changes }\end{array}$ \\
\hline & $\begin{array}{l}\text { Toxic shock syndrome toxin } 1 \\
\text { (TSST-1) }\end{array}$ & Lymphocytes T & $\begin{array}{l}\text { Activates lymphocytes } \mathrm{T} \text {, which causes } \\
\text { massive production of cytokines and leads to } \\
\text { toxic shock syndrome }\end{array}$ \\
\hline \multirow{6}{*}{$\begin{array}{l}\text { Other secreted } \\
\text { proteins }\end{array}$} & $\begin{array}{l}\text { Chemotaxis inhibitory protein } \\
\text { of Staphylococcus (CHIPS) }\end{array}$ & Neutrophils & $\begin{array}{l}\text { Binds to cell receptors (FPR1 and C5aR) } \\
\text { inhibiting neutrophils chemotaxis, thereby } \\
\text { preventing phagocytosis }\end{array}$ \\
\hline & $\begin{array}{l}\text { Staphylococcal complement } \\
\text { inhibitor (SCIN) }\end{array}$ & Complement (C4, C3b) & $\begin{array}{l}\text { Inhibits complement activation, thus } \\
\text { preventing bacterial lysis, opsonization } \\
\text { and phagocytosis }\end{array}$ \\
\hline & SSL-5 & Neutrophils, platelets & $\begin{array}{c}\text { Binds to cell receptors (PSGL-1 and GPCRs) } \\
\text { inhibiting neutrophil diapedesis and } \\
\text { activation; activates platelets } \\
\text { (aggregate formation) }\end{array}$ \\
\hline & SSL-7 & IgA, complement (C5) & $\begin{array}{l}\text { Binds } F_{c} \text { region of } \operatorname{IgA} \text { and complement } \\
\text { protein } \mathrm{C} 5 \text {, thus blocking antibodies and } \\
\text { inhibiting complement activation }\end{array}$ \\
\hline & $\begin{array}{c}\text { Extracellular } \\
\text { fibrinogen-binding protein } \\
(\mathrm{Efb})\end{array}$ & $\begin{array}{l}\text { Fibrinogen, blood } \\
\text { platelets, complement }\end{array}$ & $\begin{array}{l}\text { Binds fibrinogen enabling adhesion and } \\
\text { aggregation: interferes with platelet } \\
\text { aggregation; inhibits complement activation }\end{array}$ \\
\hline & $\begin{array}{l}\text { Extracellular adherence } \\
\text { protein (Eap) }\end{array}$ & ICAM-1 & $\begin{array}{l}\text { Binds ICAM-1 inhibiting neutrophil rolling } \\
\text { and migration (diapedesis) }\end{array}$ \\
\hline
\end{tabular}

S. aureus produces multiple proteins that interfere with complement activation [39,43,44]. The most versatile one, SCIN, blocks all three pathways by inhibiting C 3 convertases and thereby decreasing $\mathrm{C} 3 \mathrm{~b}$ deposition, $\mathrm{C} 5$ convertase formation and the release of chemoattractant C5a $[43,45]$. Another important factor, Efb, binds both C3 and fibrinogen, thus covering bacteria with a thick layer of fibrinogen that shields the $\mathrm{C} 3 \mathrm{~b}$ and antibodies from recognition by phagocytic receptors [46]. Several cell wall-associated proteins also inhibit complement activation-Cna binds to C1q and, therefore, inhibits the classical pathway [47], while SdrE recruits factor $\mathrm{H}$ to the surface of staphylococci, leading to inhibition of the alternative pathway [48]. In addition, S. aureus secretes proteases that degrade the complement proteins, including Aur and Scp A [49,50]. Together, these evasion mechanisms lead to a reduction in the complement-aided phagocytosis of bacteria and inhibition of MAC formation.

Phagocytes are the most important components of innate immunity that migrate to the site of infection and represent another line of host defense against pathogens. Neutrophils are abundantly present in blood, while macrophages reside in tissues or derive from circulating monocytes, but both play a key role in recognizing, engulfing and killing staphylococci [40,51-53]. Most clinical strains of S. aureus produce a polysaccharide capsule that protects cell wall proteins from being recognized by the phagocyte receptors $[39,54,55]$. Coagulase and ClfA also play an important role in avoiding phagocytosis-coagulase activates prothrombin to polymerize fibrinogen $(\mathrm{Fg})$, whereas ClfA allows staphylococci to bind Fg. Both these events lead to fibrin-/ fibrinogen-bacteria clump formation [56-58]. The 
formation of a fibrin network or fibrinogen clumps protects the bacteria from neutrophil clearance [40]. However, if the phagocytes manage to ingest $S$. aureus cells, the real attack begins inside the phagosome, where the bacteria are subjected to high levels of reactive oxygen species (ROS), enzymes and antimicrobial peptides (AMPs) [52]. S. aureus uses multiple strategies to interfere with both oxygen-dependent and -independent bactericidal mechanisms. One of them is staphyloxanthin-a carotenoid pigment that scavenges free radicals and gave $S$. aureus its name $[59,60]$. Additionally, this pathogen produces several enzymes that prevent ROS formation, such as superoxide dismutase (SOD), which converts superoxide radicals into hydrogen peroxide, and catalase, which further degrades it into water and oxygen [60-62]. Staphylococci reduce the negative charge of their membranes and cell walls through the incorporation of D-alanine into teichoic acid and L-lysine into membrane phosphatidylglycerol, in order to protect themselves against positively charged antimicrobial peptides (AMPs) [63]. They also secrete factors that degrade cathelicidin LL37 (Aur) and $\alpha$-defensin (SAK), as well as inhibit neutrophil serine proteases (Eap) [38,40,63]. Moreover, S. aureus can persist, and even replicate in mature phagolysosome, due to adaptation to an acidic microenvironment. The influence of stress factors on staphylococci results in the formation of slow-growing subpopulations of bacteria-small colony variants (SCVs), characterized by a high resistance to antibiotics and the host defense mechanisms. It has also been suggested that during continuous contact with staphylococci, the infected macrophages eventually lose their ability to kill this pathogen, so S. aureus can multiply and then trigger cell death to disseminate throughout the body [64-66]. Finally, neutrophils and macrophages form extracellular traps (ETs), which often lead to their own death (ETosis). These traps consist of DNA, histones, AMPs, and enzymes and serve to stop spreading the pathogens and kill them, but $S$. aureus can easily escape from ETs using the nucleases and proteases [67].

S. aureus secretes numerous toxins that kill immune cells by disrupting the cell membrane (necrosis) or by inducing programmed cell death (apoptosis/autophagy/pyroptosis) to protect itself against phagocytosis, establish infection and disseminate in the host [68]. The most important pore-forming toxins include $\alpha$-hemolysin (Hla), Panton-Valentine leukocidin (PVL) and phenol-soluble modulins (PSMs). Hla is a major toxin of S. aureus in terms of contribution to the pathogenesis that is manifested in the diversity of its functions. Some of these include the disruption of epithelial and endothelial barriers, induction of inflammatory response and lysis or apoptosis of immunocompetent cells [58,68-70]. Alpha toxin lyses a wide range of human cell types (e.g., erythrocytes, platelets and leukocytes, including T cells), while PVL targets mainly neutrophils, monocytes and macrophages. Although PVL is produced by only $2-3 \%$ of $S$. aureus isolates, it is found in most communityacquired MRSA strains, especially those responsible for pneumonia [68,71,72]. Another class of toxins are PSMs, or amphipathic peptides with considerable cytolytic activity against many types of eukaryotic cells, e.g., bone cells, endothelial and epithelial cells, monocytes, erythrocytes and mostly against neutrophils [68,73]. Their function is inhibited by serum lipoproteins; thus, they reach a high concentration inside the condensed phagosomes [74]. PSMs are associated with enhanced virulence in CA-MRSA skin infections [75].

S. aureus is successful in avoiding not only the innate immune system but also in interfering with the development of an antigen-specific response. For this purpose, it uses, for instance, surface-bound protein SpA that can bind the immunoglobulins, TNF $\alpha$ receptor 1 , von Willebrand factor and $\mathrm{C} 1 \mathrm{qR}$ component of the complement. SpA is expressed by most clinical isolates [76-78]. This protein consists of five immunoglobulin-binding domains capable of binding both the Fc regions of IgG and IgM, thus blocking opsonophagocytosis and complement activation, as well as the Fab domain of some immunoglobulins, including variable heavy 3 (VH3) of the $\mathrm{B}$ cell receptors, which leads to the activation and clonal expansion of B cells $[77,79]$. As a result, the B cells recognize, almost exclusively, protein A and the host response against other staphylococcal virulence factors is then limited [78]. Moreover, S. aureus also manipulates the T cell response by staphylococcal superantigens (e.g., TSST-1, enterotoxins) that non-specifically activate T cells by cross-linking the major 
histocompatibility complex of class II and the T cell receptor (TCR). This causes a massive activation of $\mathrm{T}$ cells and the release of proinflammatory cytokines (cytokine storm), leading to life-threatening toxic shock syndrome and multi-organ dysfunction [80-82].

In summary, S. aureus has evolved multiple strategies to avoid the host immune system response, which contributes to difficulties in both treating staphylococcal infections and developing preventive options such as vaccine or immune therapy. However, attempts are constantly being made to win this fight.

\section{Past and Present in Active and Passive Immunotherapy of Staphylococcal Infections}

S. aureus is one of the best-known bacteria in terms of virulence factors and their participation in pathogenesis. A wide repertoire of staphylococcal adhesive molecules, toxins and enzymes seems to be an excellent starting point to choose proper antigens for vaccine development. Conversely, such diversity allows these bacteria to avoid the activity of specific antibodies by replacing one virulence factor with another during a regular life cycle or by using toxins and enzymes to dampen the immune response. For example, many staphylococcal adhesive molecules from MSCRAMMs are capable of interacting with the same host extracellular matrix proteins (ECM), which is why blocking just one of them does not limit $S$. aureus adhesion and biofilm formation [38,83]. Moreover, as described in Section 2, S. aureus cytotoxins, such as hemolysins, leukocidins and PSMs, effectively damage immune cells, including neutrophils, monocytes, macrophages, dendritic cells (DC) and lymphocytes. Given the adaptive immune response, the elimination of B lymphocytes through the formation of pores in cell membranes or through the activation of programmed cell death seems to be of particular importance [38,51,84]. It is also worth mentioning yet againthe ability of $S$. aureus surface protein A (SpA) to bind the Fc domains of $\operatorname{IgG}$ and IgM, which blocks their interaction with the immune cells and the activation of the complement $[77,79]$. Furthermore, $\alpha$-toxin and other staphylococcal immunogenic antigens secreted into host tissues very often interact with specific B lymphocytes and antibodies away from the site of $S$. aureus, causing cell inactivation without co-stimulating a signal from the T lymphocytes [84]. Taking all this into account, the creation of an effective anti-staphylococcal vaccine is quite difficult, similar to the usage of specific antibodies in passive immunotherapy.

The first vaccine programs targeting single $S$. aureus virulence factors ended in failure. The vaccine containing iron surface determinant B (IsdB), necessary for iron acquisition, did not pass the safety tests. In the phase IIb/III clinical trials the V710 vaccine increased the mortality of immunized humans because of $S$. aureus infections. Nishitani et al. [85] proved with a mouse model that the antibodies specific to IsdB facilitated bacterial entry into the leukocytes, and their dissemination was the cause of increased host susceptibility to sepsis following an S. aureus local infection. Thus, anti-IsdB antibodies may be, at least in part, the cause of the V710 vaccine failure [85]. The StaphVax vaccine, comprising two predominant staphylococcal capsular polysaccharide (CP) serotypes (CP5 and CP8) conjugated to the recombinant Pseudomonas aeruginosa exoprotein A, was one of the first bivalent preparations developed; it achieved phase III efficacy studies and failed [7,86]. The formula: capsular polysaccharide with an immunogenic protein carrier that has been successfully used in the vaccines against such pathogens as Neisseria meningitidis (CP conjugated to the nontoxic recombinant variant of tetanus toxin) or Streptococcus pneumoniae (CP conjugated to the nontoxic recombinant variant of diphtheria toxin- $\mathrm{CRM}_{197}$ or surface lipoprotein D of Haemophilus influenzae). This was found to be safe but ineffective in the case of staphylococci [86-88]. Therefore, multivalent anti-staphylococcal vaccines containing a few different antigens targeting multiple virulence mechanisms started to be developed. The CP5 and CP8 (each conjugated to $\mathrm{CRM}_{197}$ ), a recombinant clumping factor $\mathrm{A}$ (rClfA) and, additionally, a recombinant lipoprotein rP305A obtained from a manganese transporter $\mathrm{C}(\mathrm{MntC})$ were used as the target antigens in the 3-antigen (SA3Ag) and 4-antigen S. aureus vaccine (SA4Ag), respectively [86,89-91]. The use of all these antigens is fully justified, not only because of their immunogenicity. As stated in the previous 
section, $\mathrm{CP}$ allows the bacteria to avoid opsonophagocytosis and elimination by the host innate immune system. ClfA, as one the most potent adhesive molecules, participates in microbial adhesion, biofilm formation and interaction with the host cells/tissues, as well as renders the bacteria coated with ECM, invisible to the immune system. MntC is a surface molecule responsible for the acquisition of manganese as a cofactor of many enzymes essential for bacterial metabolism, signal transduction, cell division and the host immune evasion [86,92]. Moreover, all of these antigens are over-produced mainly at the beginning of an infection to stabilize colonization, multiplication, possible subsequent biofilm formation and, finally, dissemination [86]. Phase I and II clinical trials in healthy adults demonstrated that the SA3Ag and SA4Ag offered acceptable safety and tolerability. Both vaccines also induced a rapid and robust immune response leading to a generation of functional specific antibodies against all antigens used, observed even through 36 months post-vaccination [89-91]. Because S. aureus surgical site infections (SSIs) followed by systemic infections (bacteremia and sepsis) are the most common and life-threatening complications of orthopedic surgeries, a search for their prevention seems particularly important. Thereby, phase IIb/III clinical trials testing the safety and efficacy of the SA4Ag in adults undergoing elective open posterior multilevel instrumented spinal fusion surgery (STRIVE study-STaphylococcus aureus suRgical Inpatient Vaccine Efficacy) were conducted. The patients who were vaccinated prior to surgery and monitored afterwards demonstrated both the safety and efficacy of the SA4Ag. Thus, similar benefits of vaccination (the prevention of postoperative $S$. aureus infections) for the patients requiring other orthopedic surgeries were suggested [86]. In 2019, the SA4Ag was described as the most advanced anti-staphylococcal vaccine; however, the studies are still in progress.

The main goal is to stop $S$. aureus infection as early as possible, to disallow the formation a resistant to immune intervention biofilm and/or to prevent later complications, such as cytokine storm and toxic shock syndrome. The current paradigm for vaccine development is targeting multiple staphylococcal virulence factors, considering both the surface antigens and secreted biologically active substances. Thus $S$. aureus adhesins and other surface proteins will generate opsonic antibodies, while non-toxic forms of toxins and superantigens will stimulate the production of neutralizing antibodies and activate effector immune cells $[93,94]$. An example of such a complex preparation is the $S$. aureus toxoid vaccine, containing modified bi-component pore-forming toxins: mutants of the $S$ and F subunits of PVL (LukS mut9 and $\left.\mathrm{LukF}_{\text {mut } 1}\right)$ and a double mutant of alpha hemolysin

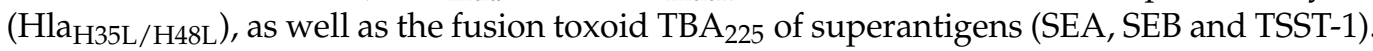
The toxoid vaccine was tested in the non-human primate model (rhesus macaques) and described as safe, well tolerated and immunogenic. The post-vaccination titers of the specific IgG with neutralizing activity were many times higher than the baseline values (from 5 to 190 times depending on the antigen). Moreover, the population of antigenspecific T cells of the Th1 and Th17 phenotype, as well as the production of some T cell cytokines (e.g., TNF, IFN- $\gamma$, IL-2, IL-17A), increased in response to ex vivo re-stimulation of peripheral blood mononuclear cells with the vaccine. It is suggested that such a T cell response may, via feedback, activate the innate immune cells that enhance phagocytosis and bacteria elimination [94].

The B cell-mediated immune response to $S$. aureus infection triggers the production of specific antibodies against many staphylococcal antigens, including cell wall components, such as peptidoglycan and lipoteichoic acid, capsular polysaccharides, pore forming toxins or superantigens [93]. Thus, on the one hand, the idea of using passive immunization as a form of antistaphylococcal therapy seems quite reasonable. On the other hand, the question is why do recurrent $S$. aureus infections happen despite the production of specific anti-staphylococcal antibodies? Regardless, many clinical trials on passive immunization with monoclonal or polyclonal antibodies against $S$. aureus antigens (e.g., ClfA, CP5 and CP8, PNAG, Hla, HlgAB) were carried out [95]. Rupp et al. [96] presented the results of a phase II randomized, multicenter, double-blind, placebo-controlled trial of polyclonal anti-S. aureus CP5/CP8 antibodies (Altastaph) in patients with staphylococcal bacteremia. 
A shortened median time of fever, as well as hospitalization, for Altastaph recipients, in comparison to the patients from the placebo group, was demonstrated. However, mortality was similar or even greater in the tested group than in control [96]. The monoclonal antibodies against LTA (Pagibaximab) or PNAG also failed in phase III or phase IIa trials, respectively [95]. Thus, passive immunization with opsonic antibodies targeting S. aureus cell wall components or envelope polymers cannot be recognized as a strategy solving the problem of staphylococcal infection treatment. Similarly, as with vaccines, the current trend in passive immunization focuses on the antibodies against secretory biologically active staphylococcal products, including pore-forming toxins. For example, human monoclonal anti-S. aureus alpha toxin antibodies, known as MEDI4893, undergo clinical trials aimed at the prevention of $S$. aureus pneumonia $[95,97]$. This strategy will be discussed in Section 4.

As specific antibodies seem not to be fully sufficient for human protection against S. aureus infections, greater attention has recently shifted to immunotherapy promoting innate immune response. The modulation of selected cytokine production and the phenotypic reprogramming of innate immune cells to develop innate immune memory as a key element of anti-infective protection are seriously considered [98-101]. Among cytokines, IL-17 seems to be critically important for the host immune response against many types of pathogens, including S. aureus. It activates CXC chemokine production (e.g., CXCL8, CXCL1, CXCL2) and, consequently, the recruitment of neutrophils to the site of infection and microorganism elimination [101,102]. Moreover, IL-17A promotes the expression of host defense peptides in the skin (in vivo studies on murine model), which are an important part of innate anti-staphylococcal response [102]. IL-17 is produced by Th17, and also by innate immune cells, such as $\gamma \delta \mathrm{T}$ cells, known to be recruited to wounds infected by $S$. aureus, and, thus, a primary source of this interleukin. Further, invariant natural killer T cells (iNKTs) and lymphoid tissue inducer (LTi)-like cells are capable of producing IL-17 [101-103]. Therefore, IL-17 and IL-17-producing cells are proposed to be the targets for novel antistaphylococcal immunotherapeutic strategies.

In the context of the importance of innate immune response and memory, the effect of prior contact of mice with $S$. aureus (priming) on the course of staphylococcal skin infection was studied $[98,99,103]$. Much smaller skin abscesses with a lower number of staphylococci were formed in the primed mice than in the naive ones. It was accompanied by a significantly increased infiltration of innate immune cells, such as PMN, M (mainly polarized to M1), DC and natural killer cells (NK) into the infection sites of the primed mice. Priming also induced greater production of some cytokines (IL-17, IL-6, IL-22, IFN- $\gamma$, MIGmonokine induced by IFN- $\gamma$ ) and antimicrobial peptides (CRAMP and m $\beta$ D-3) [98,99]. In a mouse model of $S$. aureus skin reinfection, Dillen et al. [103] showed that primary contact with $S$. aureus promoted cloning of $\gamma \delta$ T cells, producing TNF and IFN- $\gamma$, which boosted the host defense against subsequent staphylococcal infection. These observations clearly indicate that the contact with $S$. aureus triggers the development of some innate memory. Therefore, our understanding of the mechanisms of innate immune response stimulation and, in the future, their modulation to develop the "trained immunity" hold great promise for the prevention and treatment of $S$. aureus infections.

\section{The Prospects of Immune Prophylaxis Trends against S. aureus}

As discussed in detail above, achieving the GVAP goals mentioned in Section 1 will not be easy in the near future, at least for some infections. Despite huge progress in research on the bacterial species with multiple virulence and immune evasion factors, it is still difficult to find tsatisfactory tools for ensuring victory. During the development of the vaccines tested thus far, many classic methods and several new technological solutions have been used, and the expected results have yet to be achieved. Although some potential anti-S. aureus vaccines showed protective efficacy in preclinical or early clinical trials, none have been approved for use in humans to date [7,104]. Most researchers reasonably believe that we still need to learn more about new technologies in vaccine formulation and performance in order to overcome the limitations of the previous versions. The new approaches, such as 
reverse vaccinology, novel adjuvants, structural vaccinology, bioconjugates and rationally designed bacterial outer membrane vesicles (OMVs), seem promising. These lines of research, together with progress in polysaccharide conjugation techniques and antigen in silico design, could be the center of future vaccine development (VRD). As the discussion of these approaches exceeds the assumed scope of this review, we recommend several interesting links for publications on this topic [105-111].

In the final part of this review, we want to highlight only a few promising research directions [112]. An interesting perspective on vaccine "strategy" against S. aureus was proposed by Klimka et al. [113]. They suggested narrowing the composition of the vaccine to small epitopes of coproporphyrinogen III oxidase (CgoX) and triose phosphate isomerase (TPI). These epitopes fulfill essential housekeeping functions in heme synthesis and glycolysis, respectively. Two types of monoclonal antibodies (mAb), raised against CgoX and TPI, provided efficient protection against $S$. aureus infection when used for passive immunization. According to the authors, such a strategy will ensure spectacular precision of the vaccine. Their encouraging observation that in over $97 \%$ of the more than 35,000 investigated clinical strains of $S$. aureus these epitopes remain unchanged, and thus this vaccine candidate will have a broad effect, is very interesting. Therefore, "epitope-focused immunization" represents a new trend in vaccine development based on the preparation of $\mathrm{mAb}$ with narrow specificity. Monoclonal antibodies are now an integral part of the "reverse vaccinology 2.0" concept, where Abs are used to distinguish protective from non-protective epitopes and to support immune-focused antigen design. This strategy is anticipated to improve its immunogenic precision level, resulting in a vaccine with a greater efficacy and safety profile [105,114].

Alternatively, in addition to active immunization, the use of novel antibody-based passive immunization strategies, as described in Section 3, also might offer some hope. One current (though not quite new) concept is targeting the neutralization of $S$. aureus toxins. Mentioned in a previous section, the MEDI4893-human monoclonal antibodies specific to $S$. aureus $\alpha$-toxin (Hla) - have been dedicated for mechanically ventilated patients to prevent staphylococcal pneumonia. Targeting Hla as a highly conserved and pivotal $S$. aureus virulence factor participating in tissue disruption, programmed cell death, immune response dysregulation and bacterial dissemination seems to be the key to the success of immune prophylaxis. Moreover, the MEDI4893 contain a triple-amino-acid substitution in the Fc region to extend their serum half-life. A phase I clinical trial confirmed their safety and tolerability, as well as their neutralizing potential (ex vivo study) [97]. Although future studies are necessary for such a strategy to be implemented, Miller et al. [93] emphasize that $S$. aureus toxins, especially superantigens and pore-forming toxins that disrupt the host innate and adaptive immune responses are important targets in protective immunity. Therefore, naturally-generated or vaccine-induced antibodies specific to $S$. aureus toxins are, or should be, associated with improved clinical outcomes. However, there are some limitations concerning their efficacy: (i) genetic variability among humans in terms of response to the toxins, (ii) variable expression of the plethora of toxins by S. aureus strains, (iii) variable level of antitoxin antibodies production and (iv) probably different host responses to the toxins depending on anatomical sites of infection $[93,115]$. Thus, this direction of research also needs to be intensified with the use of more modern techniques and tools than those currently available.

\section{Conclusions}

As mentioned in Section 1, in 2011, as many as 25,000 deaths in the European Union (EU) were attributed to antimicrobial resistance (AMR). It is calculated that without policies and actions to stop the spread of AMR, the number of deaths in Europe could grow up to 390,000 every year by 2050. Evidence has shown that existing vaccines have a positive impact on the reduction in AMR; therefore, the recommended strategies include reasonable use of antimicrobials and greater infection control measures [116,117]. However, it is obvious that National Immunization Programs and vaccination planning in the EU should 
be integrated to meet the expectations. A clear vision for vaccine research and development (VRD) is needed in Europe to continue leading to the invention of next-generation vaccines. The Innovation Partnership for a Roadmap on Vaccines in Europe (IPROVE) has been launched. It is a collaboration among leading vaccine experts to develop a roadmap that outlines how Europe can best invest in the science and technology essential for vaccine innovation [118].

It is well accepted that to maximize the impact of vaccines in reducing the emergence of antimicrobial resistance, most of the population that is at risk of infection should be vaccinated, including all countries where the antimicrobial-resistant pathogens are endemic. Unfortunately, for most of the key AMR pathogens, vaccines are either not yet available or widespread social acceptance is unsatisfactory. More must be done to understand and address the reasons for vaccination hesitancy of the general public and healthcare professionals. The WHO and other official Health Services Reports say that while it is essential to develop new antibiotics, there is no guarantee that enough will be discovered to tackle the threat of antimicrobial resistance in the long term. Thus, other approaches (new vaccines) to prevent and treat the infections are needed. It is also strongly recommended that in the short term, the use of existing vaccines needs to be increased in both humans and animals [106-111,117].

As the world rightly focuses on limiting the spread of COVID-19, the current pandemic situation has exposed our vulnerability to the infections for which there are no effective vaccines or treatments $[105,106]$. An integrated strategy that includes multitargeted vaccines together with modern diagnostic tools, novel antibiotics, monoclonal antibodies, microbiota modulation, as well as the use of antimicrobial peptides, bacteriocins, plantderived products and bacteriophages are required to combat AMR effectively [119-124]. The still-developing research trend concerning interference with the expression of pathogen virulence factors at the molecular and submolecular levels is also very important. It is assumed that the achievements in this field may turn out to be a key tool in the modern prevention and therapy of AMR-caused infections in the near future.

Author Contributions: Conceptualization, B.S., B.R. and U.W.-B.; software, U.W.-B.; formal analysis, B.S.; data curation, U.W.-B., B.S. and B.R.; writing—original draft preparation, U.W.-B., B.S. and B.R.; writing-review and editing, U.W.-B., B.S. and B.R.; visualization, U.W.-B.; supervision, B.S.; project administration, B.S. All authors have read and agreed to the published version of the manuscript.

Funding: This research received no external funding.

Institutional Review Board Statement: Not applicable.

Informed Consent Statement: Not applicable.

Conflicts of Interest: The authors declare no conflict of interest.

\section{References}

1. Rosini, R.; Nicch, S.; Pizza, M.; Rappuoli, R. Vaccines against antimicrobial resistance. Front. Immunol. 2020, 11, 1048. [CrossRef] [PubMed]

2. Excler, J.-L.; Privor-Dumm, L.; Kim, J.H. Supply and delivery of vaccines for global health. Curr. Opin. Immunol. 2021, 71, 13-20. [CrossRef]

3. Castro, S.A.; Dorfmueller, H.C. A brief review on Group A Streptococcus pathogenesis and vaccine development. R. Soc. Open Sci. 2021, 8, 201991. [CrossRef] [PubMed]

4. Ma, L.; Caulfield, A.; Dewan, K.K.; Harvill, E.T. Pertactin-deficient Bordetella pertussis, vaccine-driven evolution, and reemergence of pertussis. Emerg. Infect. Dis. 2021, 27, 1561-1566. [CrossRef]

5. Masomian, M.; Ahmad, Z.; Gew, L.T.; Poh, C.L. Development of next generation Streptococcus pneumoniae vaccines conferring broad protection. Vaccines 2020, 8, 132. [CrossRef]

6. Stuart, J.M. Editorial for the Special Issue: Bacterial meningitis—Epidemiology and vaccination. Microorganisms 2021, 9, 917. [CrossRef] [PubMed]

7. Fowler, V.G., Jr.; Proctor, R.A. Where does a Staphylococcus aureus vaccine stand? Clin. Microbiol. Infect. 2014, 20, 66-75. [CrossRef]

8. Teymournejad, O.; Montgomery, C.P. Evasion of immunological memory by S. aureus infection: Implications for vaccine design. Front. Immunol. 2021, 12, 633672. [CrossRef] 
9. Flouchi, R.; Elmniai, A.; Hibatallah, A.; Fahsi, K.; Touzani, I.; Fikri-Benbrahim, K. The relationship between nasal carriage of Staphylococcus aureus and surgical site infections in a Hospital Center in Morocco. Int. J. Microbiol. 2021, 2021, 5585588. [CrossRef] [PubMed]

10. Lin, J.; Peng, Y.; Xu, P.; Zhang, T.; Bai, C.; Lin, D.; Ou, Q.; Yao, Z. Methicillin-resistant Staphylococcus aureus nasal colonization in Chinese children: A prevalence meta-analysis and review of influencing factors. PLoS ONE 2016, 11, e0159728. [CrossRef]

11. Sakr, A.; Brégeon, F.; Mège, J.L.; Rolain, J.M.; Blin, O. Staphylococcus aureus nasal colonization: An update on mechanisms, epidemiology, risk factors, and subsequent infections. Front. Microbiol. 2018, 9, 2419. [CrossRef] [PubMed]

12. Verhoeven, P.O.; Gagnaire, J.; Botelho-Nevers, E.; Grattard, F.; Carricajo, A.; Lucht, F.; Pozzetto, B.; Berthelot, P. Detection and clinical relevance of Staphylococcus aureus nasal carriage: An update. Expert Rev. Anti. Infect. Ther. 2014, 12, 75-89. [CrossRef] [PubMed]

13. Dayan, G.H.; Mohamed, N.; Scully, I.L.; Cooper, D.; Begier, E.; Eiden, J.; Jansen, K.U.; Gurtman, A.; Anderson, A.S. Staphylococcus aureus: The current state of disease, pathophysiology and strategies for prevention. Expert Rev. Vaccines 2016, 15, 1373-1392. [CrossRef]

14. Hoerr, V.; Franz, M.; Pletz, M.W.; Diab, M.; Niemann, S.; Faber, C.; Doenst, T.; Schulze, P.C.; Deinhardt-Emmer, S.; Löffler, B. S. aureus endocarditis: Clinical aspects and experimental approaches. Int. J. Med. Microbiol. 2018, 308, 640-652. [CrossRef] [PubMed]

15. Tong, S.Y.; Davis, J.S.; Eichenberger, E.; Holland, T.L.; Fowler, V.G., Jr. Staphylococcus aureus infections: Epidemiology, pathophysiology, clinical manifestations, and management. Clin. Microbiol. Rev. 2015, 28, 603-661. [CrossRef] [PubMed]

16. Turner, N.A.; Sharma-Kuinkel, B.K.; Maskarinec, S.A.; Eichenberger, E.M.; Shah, P.P.; Carugati, M.; Holland, T.L.; Fowler, V.G., Jr. Methicillin-resistant Staphylococcus aureus: An overview of basic and clinical research. Nat. Rev. Microbiol. 2019, 17, 203-218. [CrossRef] [PubMed]

17. Kourtis, A.P.; Hatfield, K.; Baggs, J.; Mu, Y.; See, I.; Epson, E.; Nadle, J.; Kainer, M.A.; Dumyati, G.; Petit, S.; et al. Vital signs: Epidemiology and recent trends in methicillin-resistant and in methicillin-susceptible Staphylococcus aureus bloodstream infections-United States. MMWR Morb. Mortal Wkly. Rep. 2019, 68, 214-219. [CrossRef] [PubMed]

18. van Hal, S.J.; Jensen, S.O.; Vaska, V.L.; Espedido, B.A.; Paterson, D.L.; Gosbell, I.B. Predictors of mortality in Staphylococcus aureus bacteremia. Clin. Microbiol. Rev. 2012, 25, 362-386. [CrossRef]

19. Bello-Chavolla, O.Y.; Bahena-Lopez, J.P.; Garciadiego-Fosass, P.; Volkow, P.; Garcia-Horton, A.; Velazquez-Acosta, C.; VilarCompte, D. Bloodstream infection caused by S. aureus in patients with cancer: A 10-year longitudinal single-center study. Support. Care Cancer 2018, 26, 4057-4065. [CrossRef]

20. Lu, H.Y.; Turvey, S.E. Human MALT1 deficiency and predisposition to infections. Curr. Opin. Immunol. 2021, 72, 1-12. [CrossRef] [PubMed]

21. Otto, M. Staphylococcal biofilms. Microbiol. Spectr. 2018, 6, 1-17. [CrossRef] [PubMed]

22. Schilcher, K.; Horswill, A.R. Staphylococcal biofilm development: Structure, regulation, and treatment strategies. Microbiol. Mol. Biol. Rev. 2020, 84, e00026-19. [CrossRef] [PubMed]

23. Zheng, Y.; He, L.; Asiamah, T.K.; Otto, M. Colonization of medical devices by staphylococci. Environ. Microbiol. 2018, 20, 3141-3153. [CrossRef] [PubMed]

24. Foster, T.J. Antibiotic resistance in Staphylococcus aureus. Current status and future prospects. FEMS Microbiol. Rev. 2017, 41, 430-449. [CrossRef]

25. Guo, Y.; Song, G.; Sun, M.; Wang, J.; Wang, Y. Prevalence and therapies of antibiotic-resistance in Staphylococcus aureus. Front. Cell Infect. Microbiol. 2020, 10, 107. [CrossRef] [PubMed]

26. Ippolito, G.; Leone, S.; Lauria, F.N.; Nicastri, E.; Wenzel, R.P. Methicillin-resistant Staphylococcus aureus: The superbug. Int. J. Infect. Dis. 2010, 14, S7-S11. [CrossRef] [PubMed]

27. Sakamoto, Y.; Yamauchi, Y.; Jo, T.; Michihata, N.; Hasegawa, W.; Takeshima, H.; Matsui, H.; Fushimi, K.; Yasunaga, H.; Nagase, T. In-hospital mortality associated with community-acquired pneumonia due to methicillin-resistant Staphylococcus aureus: A matched-pair cohort study. BMC Pulm. Med. 2021, 21, 345. [CrossRef] [PubMed]

28. Zhen, X.; Lundborg, C.S.; Zhang, M.; Sun, X.; Li, Y.; Hu, X.; Gu, S.; Gu, Y.; Wei, J.; Dong, H. Clinical and economic impact of methicillin-resistant Staphylococcus aureus: A multicentre study in China. Sci. Rep. 2020, 10, 3900. [CrossRef] [PubMed]

29. Centers for Disease Control and Prevention (CDC). Staphylococcus aureus resistant to vancomycin-United States, 2002. MMWR Morb. Mortal Wkly. Rep. 2002, 51, 565-567.

30. Costerton, J.W.; Stewart, P.S.; Greenberg, E.P. Bacterial biofilms: A common cause of persistent infections. Science 1999, 284, 1318-1322. [CrossRef]

31. Flemming, H.C.; Wingender, J.; Szewzyk, U.; Steinberg, P.; Rice, S.A.; Kjelleberg, S. Biofilms: An emergent form of bacterial life. Nat. Rev. Microbiol. 2016, 14, 563-575. [CrossRef]

32. Hall-Stoodley, L.; Costerton, J.W.; Stoodley, P. Bacterial biofilms: From the natural environment to infectious diseases. Nat. Rev. Microbiol. 2004, 2, 95-108. [CrossRef] [PubMed]

33. Hall, C.W.; Mah, T.F. Molecular mechanisms of biofilm-based antibiotic resistance and tolerance in pathogenic bacteria. FEMS Microbiol. Rev. 2017, 41, 276-301. [CrossRef] [PubMed]

34. Resch, A.; Rosenstein, R.; Nerz, C.; Götz, F. Differential gene expression profiling of Staphylococcus aureus cultivated under biofilm and planktonic conditions. Appl. Environ. Microbiol. 2005, 71, 2663-2676. [CrossRef] 
35. Sadowska, B.; Więckowska-Szakiel, M.; Paszkiewicz, M.; Różalska, B. The immunomodulatory activity of Staphylococcus aureus products derived from biofilm and planktonic cultures. Arch. Immunol. Ther. Exp. (Warsz) 2013, 61, 413-420. [CrossRef] [PubMed]

36. Høiby, N.; Bjarnsholt, T.; Givskov, M.; Molin, S.; Ciofu, O. Antibiotic resistance of bacterial biofilms. Int. J. Antimicrob. Agents 2010, 35, 322-332. [CrossRef] [PubMed]

37. Stewart, P.S. Mechanisms of antibiotic resistance in bacterial biofilms. Int. J. Med. Microbiol. 2002, 292, 107-113. [CrossRef]

38. Cheung, G.Y.C.; Bae, J.S.; Otto, M. Pathogenicity and virulence of Staphylococcus aureus. Virulence 2021, 12, 547-569. [CrossRef] [PubMed]

39. de Jong, N.W.M.; van Kessel, K.P.M.; van Strijp, J.A.G. Immune evasion by Staphylococcus aureus. Microbiol. Spectr. 2019, 7, 1-27. [CrossRef]

40. Pietrocola, G.; Nobile, G.; Rindi, S.; Speziale, P. Staphylococcus aureus manipulates innate immunity through own and hostexpressed proteases. Front. Cell Infect. Microbiol. 2017, 7, 166. [CrossRef] [PubMed]

41. Flannagan, R.S.; Heit, B.; Heinrichs, D.E. Antimicrobial mechanisms of macrophages and the immune evasion strategies of Staphylococcus aureus. Pathogens 2015, 4, 826-868. [CrossRef] [PubMed]

42. Shettigar, K.; Murali, T.S. Virulence factors and clonal diversity of Staphylococcus aureus in colonization and wound infection with emphasis on diabetic foot infection. Eur. J. Clin. Microbiol. Infect. Dis. 2020, 39, 2235-2246. [CrossRef] [PubMed]

43. de Vor, L.; Rooijakkers, S.H.M.; van Strijp, J.A.G. Staphylococci evade the innate immune response by disarming neutrophils and forming biofilms. FEBS Lett. 2020, 594, 2556-2569. [CrossRef] [PubMed]

44. Thammavongsa, V.; Kim, H.K.; Missiakas, D.; Schneewind, O. Staphylococcal manipulation of host immune responses. Nat. Rev. Microbiol. 2015, 13, 529-543. [CrossRef] [PubMed]

45. Rooijakkers, S.H.; Ruyken, M.; Roos, A.; Daha, M.R.; Presanis, J.S.; Sim, R.B.; van Wamel, W.J.; van Kessel, K.P.; van Strijp, J.A. Immune evasion by a staphylococcal complement inhibitor that acts on C3 convertases. Nat. Immunol. 2005, 6, 920-927. [CrossRef]

46. Ko, Y.P.; Kuipers, A.; Freitag, C.M.; Jongerius, I.; Medina, E.; van Rooijen, W.J.; Spaan, A.N.; van Kessel, K.P.; Höök, M.; Rooijakkers, S.H. Phagocytosis escape by a Staphylococcus aureus protein that connects complement and coagulation proteins at the bacterial surface. PLoS Pathog. 2013, 9, e1003816. [CrossRef]

47. Kang, M.; Ko, Y.P.; Liang, X.; Ross, C.L.; Liu, Q.; Murray, B.E.; Höök, M. Collagen-binding microbial surface components recognizing adhesive matrix molecule (MSCRAMM) of Gram-positive bacteria inhibit complement activation via the classical pathway. J. Biol. Chem. 2013, 288, 20520-20531. [CrossRef] [PubMed]

48. Zhang, Y.; Wu, M.; Hang, T.; Wang, C.; Yang, Y.; Pan, W.; Zang, J.; Zhang, M.; Zhang, X. Staphylococcus aureus SdrE captures complement factor $\mathrm{H}^{\prime}$ s C-terminus via a novel 'close, dock, lock and latch' mechanism for complement evasion. Biochem. J. 2017, 474, 1619-1631. [CrossRef]

49. Jusko, M.; Potempa, J.; Kantyka, T.; Bielecka, E.; Miller, H.K.; Kalinska, M.; Dubin, G.; Garred, P.; Shaw, L.N.; Blom, A.M Staphylococcal proteases aid in evasion of the human complement system. J. Innate Immun. 2014, 6, 31-46. [CrossRef] [PubMed]

50. Singh, V.; Phukan, U.J. Interaction of host and Staphylococcus aureus protease-system regulates virulence and pathogenicity. Med. Microbiol. Immunol. 2019, 208, 585-607. [CrossRef]

51. Guerra, F.E.; Borgogna, T.R.; Patel, D.M.; Sward, E.W.; Voyich, J.M. Epic immune battles of history: Neutrophils vs. Staphylococcus aureus. Front. Cell Infect. Microbiol. 2017, 7, 286. [CrossRef] [PubMed]

52. Pidwill, G.R.; Gibson, J.F.; Cole, J.; Renshaw, S.A.; Foster, S.J. The role of macrophages in Staphylococcus aureus infection. Front. Immunol. 2021, 11, 620339. [CrossRef]

53. Yamada, K.J.; Heim, C.E.; Xi, X.; Attri, K.S.; Wang, D.; Zhang, W.; Singh, P.K.; Bronich, T.K.; Kielian, T. Monocyte metabolic reprogramming promotes pro-inflammatory activity and Staphylococcus aureus biofilm clearance. PLoS Pathog. 2020, 16, e1008354 [CrossRef]

54. Mohamed, N.; Timofeyeva, Y.; Jamrozy, D.; Rojas, E.; Hao, L.; Silmon de Monerri, N.C.; Hawkins, J.; Singh, G.; Cai, B.; Liberator P.; et al. Molecular epidemiology and expression of capsular polysaccharides in Staphylococcus aureus clinical isolates in the United States. PLoS ONE 2019, 14, e0208356. [CrossRef]

55. Nanra, J.S.; Buitrago, S.M.; Crawford, S.; Ng, J.; Fink, P.S.; Hawkins, J.; Scully, I.L.; McNeil, L.K.; Aste-Amézaga, J.M.; Cooper D.; et al. Capsular polysaccharides are an important immune evasion mechanism for Staphylococcus aureus. Hum. Vaccin. Immunother. 2013, 9, 480-487. [CrossRef]

56. Cheng, A.G.; McAdow, M.; Kim, H.K.; Bae, T.; Missiakas, D.M.; Schneewind, O. Contribution of coagulases towards Staphylococcus aureus disease and protective immunity. PLoS Pathog. 2010, 6, e1001036. [CrossRef]

57. Herman-Bausier, P.; Labate, C.; Towell, A.M.; Derclaye, S.; Geoghegan, J.A.; Dufrêne, Y.F. Staphylococcus aureus clumping factor A is a force-sensitive molecular switch that activates bacterial adhesion. Proc. Natl. Acad. Sci. USA 2018, 115, 5564-5569. [CrossRef]

58. Tam, K.; Torres, V.J. Staphylococcus aureus secreted toxins and extracellular enzymes. Microbiol. Spectr. 2019, 7, 2. [CrossRef]

59. Clauditz, A.; Resch, A.; Wieland, K.P.; Peschel, A.; Götz, F. Staphyloxanthin plays a role in the fitness of Staphylococcus aureus and its ability to cope with oxidative stress. Infect Immun. 2006, 74, 4950-4953. [CrossRef]

60. Gaupp, R.; Ledala, N.; Somerville, G.A. Staphylococcal response to oxidative stress. Front. Cell Infect. Microbiol. $2012,2,33$. [CrossRef] 
61. Cosgrove, K.; Coutts, G.; Jonsson, I.M.; Tarkowski, A.; Kokai-Kun, J.F.; Mond, J.J.; Foster, S.J. Catalase (KatA) and alkyl hydroperoxide reductase $(\mathrm{AhpC})$ have compensatory roles in peroxide stress resistance and are required for survival, persistence, and nasal colonization in Staphylococcus aureus. J. Bacteriol. 2007, 189, 1025-1035. [CrossRef] [PubMed]

62. Mandell, G.L. Catalase, superoxide dismutase, and virulence of Staphylococcus aureus. In vitro and in vivo studies with emphasis on staphylococcal-leukocyte interaction. J. Clin. Investig. 1975, 55, 561-566. [CrossRef]

63. Joo, H.S.; Otto, M. Mechanisms of resistance to antimicrobial peptides in staphylococci. Biochim. Biophys. Acta. 2015, 1848, 3055-3061. [CrossRef]

64. Flannagan, R.S.; Heit, B.; Heinrichs, D.E. Intracellular replication of Staphylococcus aureus in mature phagolysosomes in macrophages precedes host cell death, and bacterial escape and dissemination. Cell Microbiol. 2016, 18, 514-535. [CrossRef]

65. Jubrail, J.; Morris, P.; Bewley, M.A.; Stoneham, S.; Johnston, S.A.; Foster, S.J.; Peden, A.A.; Read, R.C.; Marriott, H.M.; Dockrell, D.H. Inability to sustain intraphagolysosomal killing of Staphylococcus aureus predisposes to bacterial persistence in macrophages. Cell Microbiol. 2016, 18, 80-96. [CrossRef] [PubMed]

66. Proctor, R.A.; Kriegeskorte, A.; Kahl, B.C.; Becker, K.; Löffler, B.; Peters, G. Staphylococcus aureus small colony variants (SCVs): A road map for the metabolic pathways involved in persistent infections. Front. Cell. Infect. Microbiol. 2014, 4, 99. [CrossRef] [PubMed]

67. Speziale, P.; Pietrocola, G. Staphylococcus aureus induces neutrophil extracellular traps (NETs) and neutralizes their bactericidal potential. Comput. Struct. Biotechnol. J. 2021, 19, 3451-3457. [CrossRef]

68. Missiakas, D.; Winstel, V. Selective host cell death by Staphylococcus aureus: A strategy for bacterial persistence. Front. Immunol. 2021, 11, 621733. [CrossRef]

69. Berube, B.J.; Bubeck Wardenburg, J. Staphylococcus aureus $\alpha$-toxin: Nearly a century of intrigue. Toxins 2013, 5, 1140-1166. [CrossRef]

70. Boyle-Vavra, S.; Daum, R.S. Community-acquired methicillin-resistant Staphylococcus aureus: The role of Panton-Valentine leukocidin. Lab. Investig. 2007, 87, 3-9. [CrossRef]

71. Darboe, S.; Dobreniecki, S.; Jarju, S.; Jallow, M.; Mohammed, N.I.; Wathuo, M.; Ceesay, B.; Tweed, S.; Basu Roy, R.; Okomo, U.; et al. Prevalence of Panton-Valentine leukocidin (PVL) and antimicrobial resistance in community-acquired clinical Staphylococcus aureus in an urban Gambian hospital: A 11-year period retrospective pilot study. Front. Cell Infect. Microbiol. 2019, 9, 170. [CrossRef]

72. Graves, S.F.; Kobayashi, S.D.; DeLeo, F.R. Community-associated methicillin-resistant Staphylococcus aureus immune evasion and virulence. J. Mol. Med. 2010, 88, 109-114. [CrossRef]

73. Cheung, G.Y.C.; Joo, H.S.; Chatterjee, S.S.; Otto, M. Phenol-soluble modulins-critical determinants of staphylococcal virulence. FEMS Microbiol. Rev. 2014, 38, 698-719. [CrossRef]

74. Surewaard, B.G.; de Haas, C.J.; Vervoort, F.; Rigby, K.M.; DeLeo, F.R.; Otto, M.; van Strijp, J.A.; Nijland, R. Staphylococcal alpha-phenol soluble modulins contribute to neutrophil lysis after phagocytosis. Cell Microbiol. 2013, 15, 1427-1437. [CrossRef]

75. Berlon, N.R.; Qi, R.; Sharma-Kuinkel, B.K.; Joo, H.S.; Park, L.P.; George, D.; Thaden, J.T.; Messina, J.A.; Maskarinec, S.A.; Mueller-Premru, M.; et al. Clinical MRSA isolates from skin and soft tissue infections show increased in vitro production of phenol soluble modulins. J. Infect. 2015, 71, 447-457. [CrossRef]

76. Cruz, A.R.; Boer, M.A.D.; Strasser, J.; Zwarthoff, S.A.; Beurskens, F.J.; de Haas, C.J.C.; Aerts, P.C.; Wang, G.; de Jong, R.N.; Bagnoli, F.; et al. Staphylococcal protein A inhibits complement activation by interfering with IgG hexamer formation. Proc. Natl. Acad. Sci. USA 2021, 118, e2016772118. [CrossRef] [PubMed]

77. Deis, L.N.; Pemble, C.W., 4th; Qi, Y.; Hagarman, A.; Richardson, D.C.; Richardson, J.S.; Oas, T.G. Multiscale conformational heterogeneity in staphylococcal protein A: Possible determinant of functional plasticity. Structure 2014, 22, 1467-1477. [CrossRef] [PubMed]

78. Pauli, N.T.; Kim, H.K.; Falugi, F.; Huang, M.; Dulac, J.; Henry Dunand, C.; Zheng, N.Y.; Kaur, K.; Andrews, S.F.; Huang, Y.; et al. Staphylococcus aureus infection induces protein A-mediated immune evasion in humans. J. Exp. Med. 2014, 211, $2331-2339$. [CrossRef] [PubMed]

79. Goodyear, C.S.; Silverman, G.J. Death by a B cell superantigen: In vivo VH-targeted apoptotic supraclonal B cell deletion by a staphylococcal toxin. J. Exp. Med. 2003, 197, 1125-1139. [CrossRef] [PubMed]

80. Krakauer, T. Staphylococcal superantigens: Pyrogenic toxins induce toxic shock. Toxins 2019, 11, 178. [CrossRef]

81. Paulsen, J.; Mehl, A.; Askim, Å.; Solligård, E.; Åsvold, B.O.; Damås, J.K. Epidemiology and outcome of Staphylococcus aureus bloodstream infection and sepsis in a Norwegian county 1996-2011: An observational study. BMC Infect. Dis. 2015, 15, 116. [CrossRef]

82. Tuffs, S.W.; Haeryfar, S.M.M.; McCormick, J.K. Manipulation of innate and adaptive immunity by staphylococcal superantigens Pathogens 2018, 7, 53. [CrossRef] [PubMed]

83. Wójcik-Bojek, U.; Rywaniak, J.; Bernat, P.; Podsędek, A.; Kajszczak, D.; Sadowska, B. An in vitro study of the effect of Viburnum opulus extracts on key processes in the development of staphylococcal infections. Molecules 2021, 26, 1758. [CrossRef] [PubMed]

84. Zhang, X.; Marichannegowda, M.H.; Rakesh, K.P.; Qin, H.L. Master mechanisms of Staphylococcus aureus: Consider its excellent protective mechanisms hindering vaccine development! Microbiol. Res. 2018, 212-213, 59-66. [CrossRef] [PubMed]

85. Nishitani, K.; Ishikawa, M.; Morita, Y.; Yokogawa, N.; Xie, C.; de Mesy Bentley, K.L.; Ito, H.; Kates, S.L.; Daiss, J.L.; Schwarz, E.M. IsdB antibody-mediated sepsis following S. aureus surgical site infection. JCI Insight. 2020, 5, e141164. [CrossRef] [PubMed] 
86. Gurtman, A.; Begier, E.; Mohamed, N.; Baber, J.; Sabharwal, C.; Haupt, R.M.; Edwards, H.; Cooper, D.; Jansen, K.U.; Anderson, A.S. The development of a Staphylococcus aureus four antigen vaccine for use prior to elective orthopedic surgery. Hum. Vaccin. Immunother. 2019, 15, 358-370. [CrossRef] [PubMed]

87. Mbaeyi, S.A.; Bozio, C.H.; Duffy, J.; Rubin, L.G.; Hariri, S.; Stephens, D.S.; MacNeil, J.R. Meningococcal vaccination: Recommendations of the advisory committee on immunization practices, United States, 2020. MMWR Recomm. Rep. 2020, 69, 1-41. [CrossRef] [PubMed]

88. Principi, N.; Esposito, S. Prevention of community-acquired pneumonia with available pneumococcal vaccines. Int. J. Mol. Sci. 2016, 18, 30. [CrossRef]

89. Frenck, R.W., Jr.; Creech, C.B.; Sheldon, E.A.; Seiden, D.J.; Kankam, M.K.; Baber, J.; Zito, E.; Hubler, R.; Eiden, J.; Severs, J.M.; et al. Safety, tolerability, and immunogenicity of a 4-antigen Staphylococcus aureus vaccine (SA4Ag): Results from a first-in-human randomised, placebo-controlled phase $1 / 2$ study. Vaccine 2017, 35, 375-384. [CrossRef]

90. Nissen, M.; Marshall, H.; Richmond, P.; Shakib, S.; Jiang, Q.; Cooper, D.; Rill, D.; Baber, J.; Eiden, J.; Gruber, W.; et al. A randomized phase I study of the safety and immunogenicity of three ascending dose levels of a 3-antigen Staphylococcus aureus vaccine (SA3Ag) in healthy adults. Vaccine 2015, 33, 1846-1854. [CrossRef]

91. Creech, C.B.; Frenck, R.W.; Fiquet, A.; Feldman, R.; Kankam, M.K.; Pathirana, S.; Baber, J.; Radley, D.; Cooper, D.; Eiden, J.; et al. Persistence of immune responses through 36 months in healthy adults after vaccination with a novel Staphylococcus aureus 4-Antigen Vaccine (SA4Ag). Open Forum Inf. Dis. 2020, 7, 1-9. [CrossRef]

92. Handke, L.D.; Gribenko, A.V.; Timofeyeva, Y.; Scully, I.L.; Anderson, A.S. MntC-dependent manganese transport is essential for Staphylococcus aureus oxidative stress resistance and virulence. mSphere 2018, 3, e00336-18. [CrossRef]

93. Miller, L.S.; Fowler, V.G., Jr.; Shukla, S.K.; Rose, W.E.; Proctor, R.A. Development of a vaccine against Staphylococcus aureus invasive infections: Evidence based on human immunity, genetics and bacterial evasion mechanisms. FEMS Microbiol. Rev. 2020, 44, 123-153. [CrossRef] [PubMed]

94. Venkatasubramaniam, A.; Liao, G.; Cho, E.; Adhikari, R.P.; Kort, T.; Holtsberg, F.W.; Elsass, K.E.; Kobs, D.J.; Rudge, T.L., Jr.; Kauffman, K.D.; et al. Safety and immunogenicity of a 4-component toxoid-based Staphylococcus aureus vaccine in rhesus macaques. Front. Immunol. 2021, 12, 621754. [CrossRef] [PubMed]

95. Raafat, D.; Otto, M.; Reppschläger, K.; Iqbal, J.; Holtfreter, S. Fighting Staphylococcus aureus biofilms with monoclonal antibodies. Trends Microbiol. 2019, 27, 303-322. [CrossRef]

96. Rupp, M.E.; Holley, H.P., Jr.; Lutz, J.; Dicpinigaitis, P.V.; Woods, C.W.; Levine, D.P.; Veney, N.; Fowler, V.G., Jr. Phase II, randomized, multicenter, double-blind, placebo-controlled trial of a polyclonal anti-Staphylococcus aureus capsular polysaccharide immune globulin in treatment of Staphylococcus aureus bacteremia. Antimicrob. Agents Chemother. 2007, 51, 4249-4254. [CrossRef] [PubMed]

97. Yu, X.Q.; Robbie, G.J.; Wu, Y.; Esser, M.T.; Jensen, K.; Schwartz, H.I.; Bellamy, T.; Hernandez-Illas, M.; Jafri, H.S. Safety, tolerability, and pharmacokinetics of MEDI4893, an investigational, extended-half-life, anti-Staphylococcus aureus alpha-toxin human monoclonal antibody, in healthy adults. Antimicrob. Agents Chemother. 2016, 61, e01020-16. [CrossRef]

98. Chan, L.C.; Chaili, S.; Filler, S.G.; Miller, L.S.; Solis, N.V.; Wang, H.; Johnson, C.W.; Lee, H.K.; Diaz, L.F.; Yeaman, M.R. Innate immune memory contributes to host defense against recurrent skin and skin structure infections caused by methicillin-resistant Staphylococcus aureus. Infect. Immun. 2017, 85, e00876-16. [CrossRef]

99. Chan, L.C.; Rossetti, M.; Miller, L.S.; Filler, S.G.; Johnson, C.W.; Lee, H.K.; Wang, H.; Gjertson, D.; Fowler, V.G., Jr.; Reed, E.F.; et al. Protective immunity in recurrent Staphylococcus aureus infection reflects localized immune signatures and macrophage-conferred memory. Proc. Natl. Acad. Sci. USA 2018, 115, E11111-E11119. [CrossRef] [PubMed]

100. Leentjens, J.; Bekkering, S.; Joosten, L.A.B.; Netea, M.G.; Burgner, D.P.; Riksen, N.P. Trained innate immunity as a novel mechanism linking infection and the development of atherosclerosis. Circ. Res. 2018, 122, 664-669. [CrossRef]

101. Maher, B.M.; Mulcahy, M.E.; Murphy, A.G.; Wilk, M.; O’Keeffe, K.M.; Geoghegan, J.A.; Lavelle, E.C.; McLoughlin, R.M. Nlrp-3driven interleukin 17 production by $\gamma \delta \mathrm{T}$ cells controls infection outcomes during Staphylococcus aureus surgical site infection. Infect. Immun. 2013, 81, 4478-4489. [CrossRef]

102. Chan, L.C.; Chaili, S.; Filler, S.G.; Barr, K.; Wang, H.; Kupferwasser, D.; Edwards, J.E., Jr.; Xiong, Y.Q.; Ibrahim, A.S.; Miller, L.S.; et al. Nonredundant roles of interleukin-17A (IL-17A) and IL-22 in murine host defense against cutaneous and hematogenous infection due to methicillin-resistant Staphylococcus aureus. Infect. Immun. 2015, 83, 4427-4437. [CrossRef] [PubMed]

103. Dillen, C.A.; Pinsker, B.L.; Marusina, A.I.; Merleev, A.A.; Farber, O.N.; Liu, H.; Archer, N.K.; Lee, D.B.; Wang, Y.; Ortines, R.V.; et al. Clonally expanded $\gamma \delta \mathrm{T}$ cells protect against Staphylococcus aureus skin reinfection. J. Clin. Investig. 2018, 128, 1026-1042. [CrossRef]

104. Clegg, J.; Soldaini, E.; McLoughlin, R.M.; Rittenhouse, S.; Bagnoli, F.; Phogat, S. Staphylococcus aureus vaccine research and development: The past, present and future, including novel therapeutic strategies. Front. Immunol. 2021, 12, 705360. [CrossRef] [PubMed]

105. Rappuoli, R.; De Gregorio, E.; Del Giudice, G.; Phogat, S.; Pecetta, S.; Pizza, M.; Hanon, E. Vaccinology in the post-COVID-19 era. Proc. Natl. Acad. Sci. USA 2021, 118, e2020368118. [CrossRef] [PubMed]

106. Gavi, The Vaccine Alliance. Available online: https://www.gavi.org/our-alliance/about (accessed on 1 December 2021).

107. World Health Organization. Implementing the Immunization Agenda 2030. Available online: https://www.who.int/ publications/m/item/implementing-the-immunization-agenda-2030 (accessed on 1 December 2021). 
108. Medical Countermeasures.gov. Partnering on Vaccines to Counter AMR Threats. Available online: https://www. medicalcountermeasures.gov/barda/cbrn/mdrvaccines / (accessed on 1 December 2021).

109. World Health Organization. Call to Action on Antimicrobial Resistance. 2021. Available online: https://www.who.int/news/ item/30-07-2021-call-to-action-on-antimicrobial-resistance-2021 (accessed on 1 December 2021).

110. CIDRAP (Center for Infectious Disease Research and Policy). Stewardship/Resistance Scan for Nov 10, 2021. Available online: https:/ / www.cidrap.umn.edu/news-perspective/2021/11/stewardship-resistance-scan-nov-10-2021 (accessed on 1 December 2021).

111. FAO. The FAO Action Plan on Antimicrobial Resistance 2021-2025; FAO: Rome, Italy, 2021; pp. 1-46, ISBN 978-92-5-134673-0. [CrossRef]

112. Ford, C.A.; Hurford, I.M.; Cassat, J.E. Antivirulence strategies for the treatment of Staphylococcus aureus infections: A mini review. Front. Microbiol. 2021, 11, 632706. [CrossRef] [PubMed]

113. Klimka, A.; Mertins, S.; Nicolai, A.K.; Rummler, L.M.; Higgins, P.G.; Günther, S.D.; Tosetti, B.; Krut, O.; Krönke, M. Epitope-specific immunity against Staphylococcus aureus coproporphyrinogen III oxidase. Vaccines 2021, 6, 11. [CrossRef] [PubMed]

114. Bidmos, F.A.; Siris, S.; Gladstone, C.A.; Langford, P.R. Bacterial vaccine antigen discovery in the reverse vaccinology 2.0 era: Progress and challenges. Front. Immunol. 2018, 9, 2315. [CrossRef]

115. Ahmad-Mansour, N.; Loubet, P.; Pouget, C.; Dunyach-Remy, C.; Sotto, A.; Lavigne, J.-P.; Molle, V. Staphylococcus aureus toxins: An update on their pathogenic properties and potential treatments. Toxins 2021, 13, 677. [CrossRef]

116. Micoli, F.; Bagnoli, F.; Rappuoli, F.; Serruto, D. The role of vaccines in combating antimicrobial resistance. Nature Rev. Microbiol. 2021, 19, 287-302. [CrossRef]

117. Vekemans, J.; Hasso-Agopsowicz, M.; Kang, G.; Hausdorff, W.P.; Fiore, A.; Tayler, E.; Klemm, E.J.; Laxminarayan, R.; Srikantiah, P.; Friede, M.; et al. Leveraging vaccines to reduce antibiotic use and prevent antimicrobial resistance: A World Health Organization action framework. Clin. Infect. Dis. 2021, 73, e1011-e1017. [CrossRef] [PubMed]

118. Medaglini, D.; De Azero, M.R.; Leroy, O.; Bietrix, F.; Denoel, P. Innovation partnership for a roadmap on vaccines in Europe (IPROVE): A vision for the vaccines of tomorrow. Vaccine 2018, 36, 1136-1145. [CrossRef] [PubMed]

119. Dijksteel, G.S.; Ulrich, M.M.W.; Middelkoop, E.; Boekema, B.K.H.L. Review: Lessons learned from clinical trials using antimicrobial peptides (AMPs). Front. Microbiol. 2021, 12, 616979. [CrossRef] [PubMed]

120. Lee, J.-K.; Park, Y. All d-Lysine analogues of the antimicrobial Peptide HPA3NT3-A2 increased serum stability and without drug resistance. Int. J. Mol. Sci. 2020, 21, 5632. [CrossRef]

121. Ryu, S.; Song, P.I.; Seo, C.H.; Cheong, H.; Park, Y. Colonization and infection of the skin by S. aureus: Immune system evasion and the response to cationic antimicrobial peptides. Int. J. Mol. Sci. 2014, 15, 8753-8772. [CrossRef] [PubMed]

122. Speziale, P.; Pietrocola, G. Monoclonal antibodies targeting surface-exposed and secreted proteins from staphylococci. Vaccines 2021, 9, 459. [CrossRef]

123. Swolana, D.; Kępa, M.; Kabała-Dzik, A.; Dzik, R.; Wojtyczka, R.D. Sensitivity of staphylococcal biofilm to selected compounds of plant origin. Antibiotics 2021, 10, 607. [CrossRef]

124. Walsh, L.; Johnson, C.N.; Hill, C.; Ross, R.P. Efficacy of phage- and bacteriocin-based therapies in combating nosocomial MRSA infections. Front. Mol. Biosci. 2021, 8, 654038. [CrossRef] 